\title{
Fast jobb til legene handler om pasientene også
}

I norske sykehus har bare halvparten av legene fast jobb. Arbeidsgiverne forsøker å unngå stillingsvernet, og ofrer både kvalitet og pasientsikkerhet. Johan Torgersen, leder av Yngre legers forening, tar et oppgjør med midlertidige ansettelser.

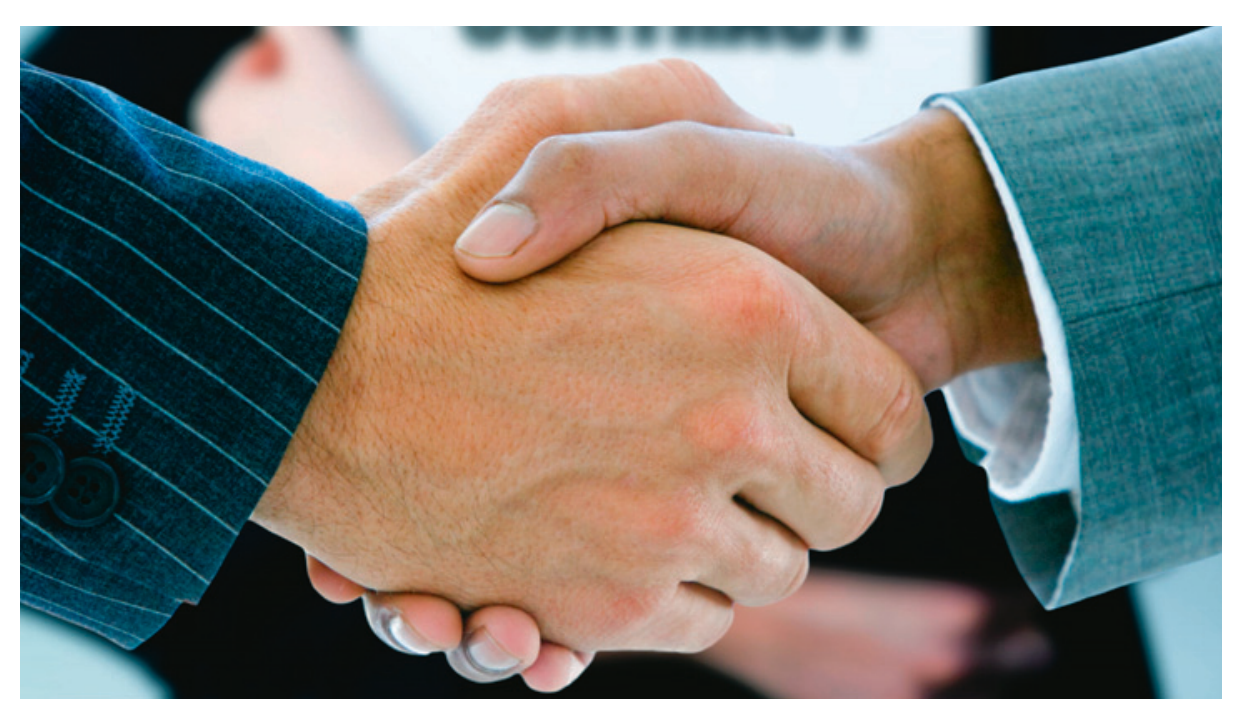

YLF-leder Johan Torgersen mener det er på høy tid at man gir leger fast jobb. Illustrasjonsfoto Wavebreak Media/Thinkstock
Johan Torgersen

Johan Torgersen (f. 1974) er leder av Yngre legers forening og sitter i Legeforeningens sentralstyre. Han er spesialist i anestesiologi og har en ph.d.-grad fra Universitetet i Bergen.

Ingen oppgitte interessekonflikter.

PUBLISERT I BLOGGEN

(b) 26.9 .2013

\section{«Kaoset er nå blitt for omfattende. Det må ryddes opp!»}

dukket opp noen uker senere. Behovet for legen var der hele tiden.

- Avdelinger finner opp nye stillinger. En av de siste er «lege i underordnet stilling», hvor spesialister ansettes midlertidig ett år om gangen. En praksis som det ikke finnes snev av hjemmel for i verken lov, forskrift eller avtale. nye spesialister og også overleger forverres dag for dag.

Da Yngre legers forening ble stiftet i 1911, var bakgrunnen behovet for å rydde opp i uryddige ansettelsesprosesser og stillingsforhold. Mye har endret seg siden den gang. Nå får leger i spesialisering lønn. Vi har regulert arbeidstid, selv om den ligger langt utenfor grensene i arbeidsmiljøloven. Stort sett har vi også arbeidskontrakter.

La meg komme med noen helt konkrete eksempler på dagens situasjon for leger.

\section{Får ikke varsle om kritikkverdige forhold}

- «Sjefen min kalte meg inn til et møte, hvor jeg fikk følgende beskjed: Du er en flink lege, du! Du gjør en god jobb med pasientene dine, men dessverre er du så kritisk til de endringene vi må gjøre ved klinikken vår. Når du viser slik motstand i prosessene vi står i, kan du ikke regne med å ha en fremtid ved denne klinikken.» Den tillitsvalgte legen ved et større norsk sykehus gjorde ikke annet enn det hun er forpliktet til, nemlig å si ifra når virksomheten organiseres på en måte som ikke gjør det mulig for helsepersonellet å innfri kravet om forsvarlig behandling.

- Et av de vanligste svarene jeg får, som mangeårig sentral tillitsvalgt for leger i spesialisering, når jeg ber leger og tillits-

\section{Opphør av ansettelsesforhold}

valgte om å ta opp kritikkverdige, ulovlige forhold er: «Det vil jeg ikke, jeg ønsker jo å fortsette å jobbe her.»

- Legeforeningen har bistått 12 gravide leger som har mistet jobben. Legene har fătt medhold i samtlige saker av Likestillings- og diskrimineringsombudet (LDO). Helseforetakene er av Likestillings- og diskrimineringsombudet beskrevet som likestillingsverstinger. Sakene vi har tatt videre, er sannsynligvis kun toppen av isfjellet.

- Leger som har fullført en langvarig hovedspesialisering, grenspesialisering og sin relevante doktorgrad får beskjed om at de ikke lenger er ønsket i avdelingen og må slutte. Flere begynner på nytt igjen med spesialisering innen et nytt fag. Å ikke bruke kompetanse som det er investert store midler i å bygge opp, er en samfunnsøkonomisk skandale.

- Legevikariater i sykehusene anvendes ikke i tråd med loven, og brukes for å skjule ulovlige, midlertidige ansettelser.

\section{«Kreative» kontrakter}

- Leger jobber uten arbeidskontrakter. Ansettelsesforholdet videreføres kun ved tilfeldig oppdatering i styringsverktøyet GAT med for eksempel 1-2 måneders varighet.

- En lege måtte forlate jobben i noen uker uten lønn for så å være velkommen tilbake i samme jobb da et nytt vikariat på 2-3 uker som forlenges fortløpende.

Og hvis man er misfornøyd er en vanlig uttalelse fra ledere: «Jasså, så du er ikke fornøyd med arbeidssituasjonen din? Det er bare å slutte. Lista av søkere til vikariater er lang!». Dessverre er situasjonen at

- I 2013 er $95 \%$ av alle leger i spesialisering midlertidig ansatt, i 1985 var andelen $75 \%$

- Over 50\% av alle leger er midlertidig ansatt

- Leger tilbringer i snitt over $1 / 3$ av yrkeskarrieren sin i en midlertidig ansettelse

\section{Er dette smart bruk av leger?}

- Nei!

- Hvem taper på denne ukulturen?

- Alle!

Legene mangler rimelig forutsigbarhet i over en tredel av yrkeskarrieren sin. Sykehusene går glipp av leger med sterkt eierskap til virksomheten sin, som tør stikke hodet frem for å bidra til forbedringer eller ning. Ikke minst taper pasientene på at over
- Det finnes eksempler på «vikariater» som tør si ifra når ledelsen velger feil ret- 
$50 \%$ av legegruppen ikke har grunnlag for å engasjere seg fullt og helt og med tydelig stemme på vegne av pasientsikkerhet og kvalitet.

\section{Hvorfor er det blitt slik?}

Midlertidigheten er grodd så fast i stillingsstrukturen til leger i sykehus at det stilles få spørsmål ved en stadig mer rotete og skadelig praksis. Vi er vant med å få servert arbeidsforhold som ligger langt unna det som er vanlig i norsk arbeidsliv. Kaoset er nå blitt for omfattende. Det må ryddes opp!

\section{Hva må gjøres?}

Leger må få den samme retten til fast ansettelse som er normen ellers i samfunnet. Dette er et politisk ansvar å få gjennomført. Helse- og omsorgsdepartementet eier sykehusene og må gi et klart styringssignal nå. Det gjør de på andre politiske områder som er aktuelle i sykehusene. Beskjeden må gis til helseforetakene akkompagnert av gjennomføringsvilje.

Snart kommer det en ny regjering ut på Slottsplassen i Oslo, hvor Høyre vil dominere. Hvem helseministeren blir, vet vi ikke med sikkerhet. Det vi vet, er at nåværende leder i Helse- og omsorgskomiteen på Stortinget, Bent Høie, i en interpellasjon i Stortinget i 2010 slo fast at praksisen med midlertidig ansettelse av leger i spesialisering var en trussel for pasientsikkerheten. Stortingsvalget i september har ikke endret på dette faktum. Nå får Høyre muligheten til å tette dette pasientsikkerhetshullet.

Planene er klare, trykk på knappen, sett faste stillinger for leger i spesialisering ut i livet.

Kommentarer til og diskusjoner om innlegget finner du på blogg.tidsskriftet.no Vil du blogge, ta kontakt. 